\title{
Data Transparency in Covid-19 Countermeasures Policy (Case Study of Central Java Provincial Government)
}

\author{
Yuliana Kristanto ${ }^{1}$, Amni Zarkasyi Rahman ${ }^{2}$, Retna Hanani ${ }^{3}$ \\ \{yulianakristanto@lecturer.undip.ac.id ${ }^{1}$ \} \\ Universitas Diponegoro, Indonesia ${ }^{1,2,3}$
}

\begin{abstract}
The Covid-19 pandemic that attacks most countries in the world, including Indonesia, shows an increase over time and causes more casualties and material losses, which have implications for social, economic and social welfare aspects. In accordance with the President's instructions, the policy to prevent the spread of Covid-19 has become the autonomy of each local government in Indonesia. Local governments are expected to realize the urgency of data transparency for the public in their policies because data transparency is one form of government accountability in realizing Good Governance. In this study, the researcher wanted to examine the implementation of good governance in the aspect of data transparency in Central Java province related to Covid-19. Central Java Province is a province that is in the top seven with the highest number of Covid-19 sufferers in Indonesia (update data until July 10, 2020). In this study, researcher's processed big data from 36 online mass media articles from March to June 2020 which contained the statement of the Governor of Central Java. Then processed using the Orange application.
\end{abstract}

Keywords: Covid-19, Policy, Good Governance, Data Transparency, Central Java Province, Orange Application

\section{Introduction}

Almost all parts of the world are now faced with the same problem, the Covid-19 Pandemic (Corona Virus Disease-19). This pandemic situation was able to destroy social activities, the economic sector, politics, and even education. The countries affected implementing various strategies to contain the epidemic to efforts to reduce its impact on the country's growth. One of them is Indonesia. in accordance with Presidential Decree 7 of 2020 concerning the Task Force for the Acceleration of Handling of Corona Virus Disease 2019 (Covid-19) which instructs the Regional Government to have full authority in managing efforts to prevent the spread of Covid19.

The policy of each Regional Government in providing adequate health services is a national strategy in tackling Covid-19. Interestingly, not all local governments enforce the same policies. This is because the capacity of each region varies in fulfilling adequate facilities, especially in data management and transparency. In line with the presidential instruction, in various regions the community does not only need health services but also demands for information transparency. Especially information about the number of PUS (Patient Under Supervision), to the Insider Monitoring in their local areas. This data transparency issue is considered by the public as a normal thing for the government to do because the community is 
in a position of worry and confusion with the pandemic situation. So, that transparency of information and data can be the basis for community steps to act. Unfortunately, the needs of the community are not always responded to well by the Government, especially local governments. As evidence on the information provider website in Central Java Province, there was a difference between Covid-19 data in Central Java Province and central government data $[1]$.

Transparency in providing this information is related to the formulation of policies carried out by the government for the community. To realize good governance or good governance, transparency in public policy is needed. Good Governance itself is a fundamental right for citizens to their government. Some important points from obtaining the right to good governance are the right to information, press freedom, environmental protection [2].

According to the Gisselquist [2] Theory, good governance is based on the following indicators:

a. Putting all activities on demand driven,

b. Development of community-oriented activities and seeking community participation,

c. Ensure transparency in administration and decision-making processes,

d. Increase efficiency and effectiveness in basic services,

e. Ensuring equality in the process of distributing benefits to those in need.

The government, in this case the Regional Government of Central Java Province, has the capacity and resources to provide open information to the public in an effort to provide public services. Transparency and accountability are the keys to efforts to realize Good Governance.

This paper has an urgency to see how often the data transparency becomes part of Local Government policies related to efforts to tackle the Covid-19 outbreak in society. Especially in the Central Java Provincial Government.

\subsection{Purposes of The Research}

This research aimed to:

a. Knowing how often data transparency is part of the Covid-19 response policy in Central Java Province.

b. Analyze data transparency policies with the efforts to realize Good Governance.

\subsection{Theoretical Concept}

\subsubsection{Public Policy}

Public policy can be defined as actions, objectives and statements of the government regarding certain problems; the steps which have been or are being taken to be implemented; and the explanations they provide about what has happened or has not happened [3]. Public policy can be simply stated as what "is whatever government decides to do or not to do" [4].

Public policy is a government policy that affects everyone in a country or state or policy in general. The goal of public policy itself is to achieve public welfare through regulations made by the government. Because the process is long and aims for the benefit of society, transparency is needed in policy making. 


\subsubsection{Good Governance}

Good governance is basically a concept that refers to the process of achieving decisions and their implementation which can be accounted for collectively. As a consensus reached by the government, citizens and the private sector for governance in a country. The main key to understanding good governance is understanding the principles in it, namely: Participation, Rule of Law, Transparency, Private Sector Engagement, Equity, Effectiveness and Efficiency, and Accountability.

The concept of transparency is part of the principles of good governance. In government systems, the concept of transparency is used as a subject of analysis in the fields of negotiation theory, international security, and the effectiveness of a regime [5].

\section{Method}

The method used in this research is mass media text analysis. Namely collecting as many as 36 online mass media articles. Because the subject of this study is the Central Java Provincial Government, the researchers used the largest mass media in Central Java, Suara Merdeka. Through the online channel is suaramerdeka.com, researchers collect news about the Covid-19 policy delivered by Governor Ganjar Pranowo. The time period chosen was the beginning of the spread of Covid-19 in Central Java, start from March 2020 until June 2020 which is entering New Normal. From the primary data, all texts in the selected mass media were then processed using Text Mining in the Orange application. By going through the data cleaning process or removing inconsistent data noise by using the stop word feature. Basically, text mining is defined as the process of extracting information where users interact with a collection of documents from period to period using an analysis tool [6].

\section{Result and Discussion}

\subsection{Policies of the Central Java Provincial Government Regarding Covid-19 that have been Carried Out}

The spread of Covid-19 cases in Central Java began in March 2020 and began with the discovery of new cases in Surakarta City. After that, another case in Purwokerto followed. To overcome the spread of the Covid-19 virus from spreading, the Central Java Provincial Government from March to July 2020 has implemented several policies related to overcoming the Covid-19 virus. Some of them are:

a. In March 2020 the Governor of Central Java issued a Circular Number 440/0005942, concerning Increased Alertness Against the Risk of Corona Virus Infection Transmission (Covid-19) in Central Java. In the letter, Ganjar conveyed that prevention and control efforts were needed through four steps, namely coordination, socialization and education regarding prevention and control efforts to elements of society and business actors according to their authority. One of the implementations of this Circular Letter is the policy to prohibit all cruise ships from docking at all ports in Central Java. In the same month the government officially imposed SFH (Study from Home) and all tourist objects in Central Java were gradually closed to the public. This was followed by the enactment of the Covid- 
19 emergency response status, which was stated in the Governor of Central Java Decree Number 360/3/2020 concerning the Determination of the Corona Virus Disease (Covid19) Emergency Response Status in Central Java Province, from March 202020 to 29 May 2020.

b. In April, check points began to be established to overcome the ban on homecoming which was officially enforced in May. The obligation to wear masks in public places such as traditional markets has also been implemented to comply with health protocols.

c. In May the number of Covid-19 cases in Central Java began to increase, and every area in Central Java Province found new cases. This month, basic needs assistance as well as in the form of money began to be often given by the Central Java Provincial Government because the number of layoffs was increasing. The Large-Scale Social Restriction Policy is increasingly being implemented. Business actors are advised to close their businesses at 20.00 WIB.

d. On 2 June 2020 Governor Ganjar Pranowo gave a statement that the Central Java Provincial Government would not rush to take the New Normal Step for the case curve that had not decreased. At the end of June, the City of Semarang took policy steps to intensify mass tests for the community (Data sources: 36 online mass media articles processed by researchers).

From all the policies taken and delivered by the Governor of Central Java, it can be seen that the statement regarding the exact number or number of Covid-19 patients, both positive and under surveillance, has not been mentioned much. The Central Java provincial government itself has a standby web that is used to update the number of cases that have occurred in Central Java. However, this website had undergone several repairs from March to April.

\subsection{Data Transparency in Various Central Java Provincial Government Policies Related to the response to Covid-19}

From all policies from the beginning of the Covid-19 pandemic in Central Java, period March 2020 to the enactment of the New Normal period in June 2020, this study wants to determine the level of frequency or how often data transparency problems are a concern in policy making.

The method used in this research is to process all the data obtained, namely 36 text articles of mass media online and through the text mining process in the Orange application, the result is as shown in Figure 1.

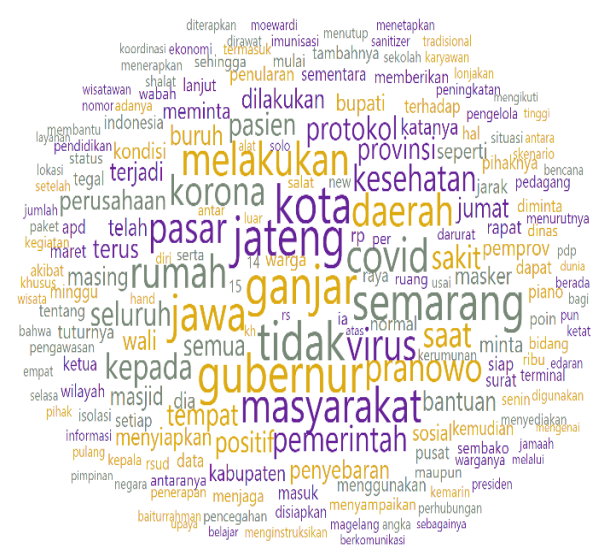

Fig. 1. Results of Text Mining Processing on Orange Data Mining. 
From the results of this processing, it can be seen that the words data transparency, data accountability and numbers are not words that have the highest frequency that appear in every statement of the Governor of Central Java in conveying his policies.

From the figure 2 shows that the word data, transparency and numbers only have an appearance frequency of 13 times of the entire mass media text that is made of data from totally 9625 words. The entire text has undergone Data Cleaning (eliminates inconsistent data noise). When compared with other word frequencies, namely policies on handling Covid-19 in public places such as traditional markets, which have the frequency of appearance in each policy was 46 times. Of course, there will be quite a distant comparison.

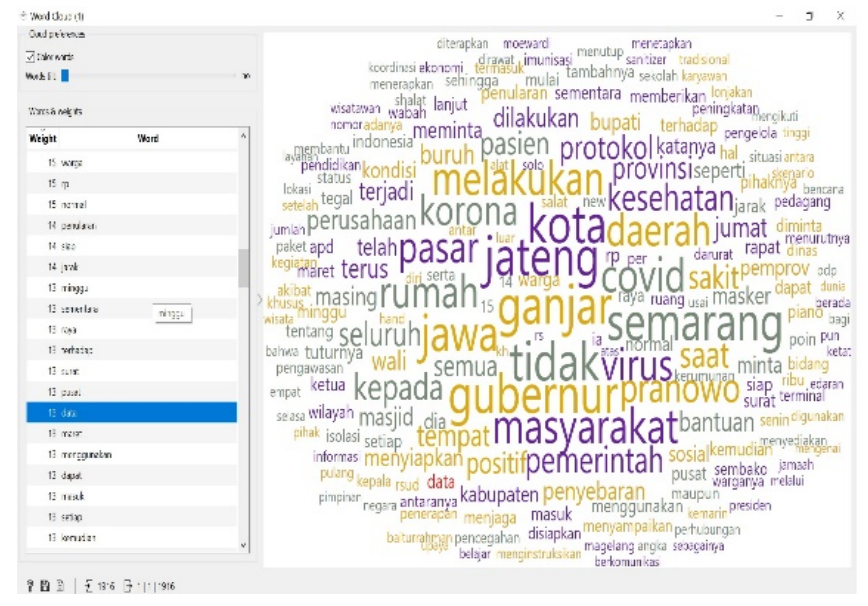

Fig. 2. Results of Text Mining Processing on Orange Data Mining.

The frequency of the text "data, numbers" was used in several statements uttered by the Governor Ganjar Pranowo as follows:

a. For case updates, Ganjar said, "They have been intensively communicating with the central and district/city governments. Because it is prone to resistance, according to Ganjar, all layers of government must unite in facing Covid-19. Both in presenting data and handling".

b. He continued that he has calculated the social impacts that arise in Central Java. The Social Service, continued Ganjar, has collected data and calculations.

c. "Data on every migrant who returns home, check their health, and continue to monitor them. The same protocol must also be applied at the village level, even in RT and RW"

From several statements by the Regional Head above, the use of the word "Data" is not used with the inclusion of a definite number. But more leads to information on an activity.

From the results of processing using Text Mining, it shows that the problem of data and transparency of numbers has not become an issue that is considered important and is widely involved in policy making that is disseminated to the public.

\subsection{The Relationship Between Data Transparency and the Realization of Good Governance}

An important element in the process of realizing Good Governance is the aspect of transparency. Transparency in policy is the strongest element in informing policy choices that 
can be chosen by the public to increase the interests of the community's welfare. Effective policy transparency can be done by applying the following principles:

a. Provide information that is easy to use by the community. In the case of overcoming Covid-19 in the Central Java Provincial Government, the Government has provided a website to access updated data on the number of cases of Covid-19 sufferers in Central Java. However, this data is not always sounding to public by the regional head. So that policy recipients may not have a clear picture of the reasons for choosing the policy. This is evident from the low frequency of Regional Heads talking about data.

b. Stakeholders help policy targets understand how when the choices in the policy change. Especially in policies related to the response to Covid-19, if it is accompanied by transparency of information on numbers and data that continues to change, the community as the target of policy targets will more easily accept policy changes that occur. In this case, policy transparency will fail if stakeholders are unable to differentiate between civil societies options on the reasons why they change or are unable to provide those choices.

\section{Conclusion}

Based on the results of data processing carried out on 36 online mass media articles using Orange Data Mining processing, it can be concluded that the problem of data transparency and the number of Covid-19 cases has a low frequency to appear in various policies of the Central Java Provincial Government in the context of overcoming Covid-19, namely as much as 13 times the word data appeared from the total 9625 words that were processed.

Meanwhile, the highest frequency of texts that appeared was related to Ganjar Pranowo as the Regional Head and the regulation of market activities during the Covid-19 pandemic. From this highest frequency it can be concluded that the delivery of policies is correct by means of direct socialization by the Regional Head. This is in line with Presidential Decree/Keppres 7 of 2020 concerning the Task Force for the Acceleration of Handling of Corona Virus Disease 2019 (Covid-19) which instructs the Regional Government to have full authority in managing efforts to prevent the spread of Covid-19.

With regard to efforts to realize Good Governance, including the concept of transparency in policies, principles that must be met in order for policies to be effective, such is the provision of information that is easy to use by the public and stakeholders to help policy targets understand that the choices in these policies can change. Of the two concepts of transparency, the problem of data transparency in the policy of overcoming Covid-19 in Central Java Province cannot be fulfilled optimally.

\section{References}

[1] V. Ardyansah, "Data Covid-19 Jateng dengan Pemerintah Pusat Beda, Ini Kata Dinkes," 2020. [Online]. Available: https://www.ayosemarang.com/read/2020/04/17/55504/data-Covid-19jateng-dengan-pemerintah-pusat-beda-ini-kata-dinkes.

[2] R. M. Gisselquist, Good Governance as a Concept, and Why this Matters for Development Policy, no. 2012/30. WIDER Working Paper, 2012.

[3] A. Wahab, Analisis Kebijakan. Bumi Aksara, 2012.

[4] J. M. Shafritz, C. Borick, E. W. Russell, and A. C. Hyde, Introducing Public Administration. Routledge, 2016.

[5] M. Bauhr and M. Grimes, "What is Government Transparency? New Measures and Relevance 
for Quality of Government," QoG Work. Pap. Ser., vol. 16, 2012.

[6] A. Sentiya, H. Suroyo, F. I. Komputer, and U. B. Darma, "Analisis Text Clustering Akun Fanpage Shopee Indonesia Dengan Komentar Followers Menggunakan Tools Orange Data Mining,” Bina Darma Conf. Comput. Sci., pp. 1055-1067. 